\title{
Effectiveness of Student Councils in Conflict Resolutions and Communication in Secondary School Management in Nyeri County, Kenya
}

\author{
Wamukuru David Kuria* Eustace Murage Muthui
}

\begin{abstract}
Schools in Nyeri County continue to face diverse conflicts in the day to day running of the schools. Amongst these conflicts include burning of school dormitory at Giakaibei Secondary in Mathira in 2016; injuring of deputy principal at Kirimara Boys High School in school riots in the same school in 2018; and school unrests in Giakabii High School, Watuka High School, Wamagana Girls, and Mwiyogo Girls in 2016. To mitigate the negative consequences of conflicts, there is need for conflict resolutions. This study sought to examine effectiveness of student councils in conflict resolutions and communication in secondary school management in Nyeri County, Kenya. Amongst the objectives of the study included examination of the challenges affecting student councils in communication for effective school Management in Nyeri County and establishing the challenges affecting student councils in conflict resolutions for effective school Management in Nyeri County, Kenya. Amongst the challenges that student councils faced in conflict resolution included lack of skills in conflict resolution, making decisions based on friendships, and threats from other students amongst others. The study thus noted need for organized forums to train students on conflict resolutions as well as need for guidance and counselling. The study found the communication challenges of the student councils to be poor masterly of English and Kiswahili language, lack of communication channels, and speaking in vernacular. The communication challenges of student councils can be mitigated through use of suggestion boxes, banning of vernacular languages, and encouragement of conversation without fear of intimidation.
\end{abstract}

Keywords: Student councils, conflict resolution, management

DOI: $10.7176 / \mathrm{DCS} / 9-3-06$

Publication date:March $31^{\text {st }} 2019$

\section{I.Introduction}

Conflicts often arise within the running of secondary schools and other institutions of learning across the world. According to Oboegbulem \& Alfa (2013) conflict relates to the pursuit of incompatible interests by diverse groups. Oboegbulem \& Alfa (2013) further state that conflict is the entails discord in actions, lack of concordance in opinion in order to achieve one's own goal. Wairimu (2016) notes that conflict relates to the misunderstanding arising between groups of people with incompatible goals occurring as a result of communication breakdown aspects.

Within the secondary school set up, conflicts may arise between different school stakeholders such as between school administration and parents, school administration and students, school administration and ministry of education officials, between school sponsors and ministry of education and amongst students themselves (Betty, Kiprop, \& Bomett, 2011; Owande, 2015; Kipyego, 2013; Nyasio, 2015; Muthui \& Barchok, 2017). However, the conflict between school administration and students are often more common in nature and more destructive in nature. Amongst the causes of conflicts between school administration and students including dissatisfaction in relation to food quality and portions served in school, school management aspects and discipline levels, head teacher transfers, examination performance, school indiscipline cases and school trips amongst others (Kipyego, 2013; Edet, Benson, \& Williams, 2017; Vundi, 2017; Orapeleng, 2017).

Conflict within the school sect up have been found to have various consequences including disruptions of academic programmes (Oboegbulem \& Alfa, 2013); teachers concern on their safety aspects (Oboegbulem \& Alfa, 2013); school closures (Oboegbulem \& Alfa, 2013); physical injuries; property destruction; strikes and boycotts (Ogonyo, 2012; Wangui, 2015; Zablon, Areba, Monga, Rael, \& Robert, 2014); school fires (Mburu, 2012; Ngema, 2013) amongst other challenges. To mitigate the negative consequences of conflicts, there is need for conflict resolutions. According to Oboegbulem \& Alfa (2013) conflict resolutions refers to the process of finding solutions to the conflicts. On the other hand, Edet, Benson, \& Williams (2017) view conflict resolution as the ending of conflicts through addressing remote causes of the issues with resolutions that are just and acceptable by the conflicting groups. In the conceptualization of conflict resolution, Edet et al., (2017) unlike Oboegbulem \& Alfa (2013) places an emphasis on the proposed solution to the conflict to be acceptable to the conflicting parties. This concept of acceptability of the solution by all the conflicting parties if further emphasized by Hagan (2016) in her conceptualization of conflict resolution. Hagan (2016) notes that conflict resolution is providing solutions to the conflicts through provision of opportunities to listen to the concerns of all parties, meet the compromise in the competing needs of each party and achieve a compromise acceptable to the conflicting parties. 
One of the mechanisms that have been used in conflict resolutions within secondary schools is the use of student councils. Ogol \& Thinguri (2017) indicates that the education act of 1998 mandates the principals to establish the school councils in their schools and support its functions. According to Murage, Mwaruvie, \& Njoka (2017) student councils refer to student leadership bodies that are elected by fellow students. Amongst the key functions of the school councils include the participation of the school councils in the conflict management within the schools. In this context, Vundi, Majanga, \& Odollo (2014) notes that the Kenya Secondary Schools Student Councils (KSSSC) which is an umbrella body of the student councils recognizes the involvement of the student councils in conflict resolution. This is enshrined in article I section 11 of the KSSSC constitution that captures the commitment of the organization in management of the school conflicts (Vundi et al., 2014).

This study seeks to examine the effectiveness of the student councils in conflict resolutions and communication in secondary school management in Nyeri County, Kenya. There has been several school conflicts in Nyeri County including burning of school dormitory at Giakaibei Secondary in Mathira in 2016; injuring of deputy principal at Kirimara Boys High School in school riots in the same school in 2018; and school unrests in Giakabii High School, Watuka High School, Wamagana Girls, and Mwiyogo Girls in 2016(Wanzala \& Muinde, 2018).

\section{ii.Research Objectives}

The study will be based on the following objectives;

(i) To establish the challenges affecting student councils in communication for effective school Management in Nyeri County, Kenya

To establish the challenges affecting student councils in conflict resolutions for effective school Management in Nyeri County, Kenya

\section{Iii. Literature Review}

\section{Challenges Affecting Student Councils in Communication}

The role of the student councils in communication aspects as a means of conflict resolution has been explored by diverse scholars. Kyalo, Kanori, \& Njagi (2017) examined the student councils' involvement in communication link with the school management in public secondary schools in Kathonzweni sub county Kenya. The study used a target population composed of teachers, students and principals. Amongst the communication needs that Kyalo et al., (2017) found to be achieved by student councils included presentation of students' problems, presentation of student views on welfare aspects, presentation of student views on student management, discussion on mode of punishment and discussion of overall state of the school. The study concluded that the student councils role in communication was positively associated with high discipline levels in schools. In this context, Kyalo et al., (2017) noted that the school management must consider ideas, suggestions, comments, feedback and complaints from the students.

The communication roles of the student councils were further examined by Simatwa, Ngala, \& Tikoko (2017) in a study that focused on public boys' high schools in Elgon Sub County. To achieve its results the study used descriptive survey design and a target population of 750 students for its study derived from three public boys' schools. Simatwa et al., (2017) found that the communication needs that the student councils played included communication on complaints relating to student bullying; number of examinations administered; congestion in dormitories; lateness in meal provisions; non-attendance by teachers to classes; and excessive punishment meted by teachers. Other aspects include complaints on water shortage, poor quality of food, and provision of textbooks. In relations to the influence of student councils communication with the school management and incidences of school unrests, Simatwa et al., (2017) found that there was a negative correlation relationship between the two components. Thus the higher the communication aspects the lower the incidences of school unrest aspects. The study recommended that the student councils communications should be given consideration by the school management.

Similar to studies by Kyalo et al., (2017), and Simatwa et al., (2017), Muthui \& Barchok (2017) also undertook a study that sought to examine the influence of student councils communication aspects in conflict management aspects. Muthui \& Barchok (2017) study was based in Nyeri County. The study used a sample size of 384 respondents from Nyeri County as its sample size. These students comprised both of council members and ordinary students. The study recorded that the students were challenged in communication aspects in diverse ways. Unlike the studies by Kyalo et al., (2017), and Simatwa et al., (2017), Muthui \& Barchok (2017) looked at the communication aspects from the perspective as to whether there was adequate communication levels between the student council and the students that they represented. Amongst the communication challenges that were present included failure to listen to student issues, school council failure to record student challenges, failure to present student challenges to the management, failure to consult other students, and failure to give timely communication to the management. 


\section{Student Councils and Conflict Resolution}

One of the main reasons for student councils establishment was the conflict resolution aspects. Focusing on the general high schools in Kenya, Ogol \& Thinguri (2017) undertook a study that sought to examine the influence of effectiveness of student leadership on leaners' discipline management aspects. The study was qualitative in nature and in that context used content analysis aspects. The challenges that the study documented in respect to the student councils and conflict resolution aspects included some student councils were not supported by the management, lack of training of student councils on their mandates, and school management not embracing democracy that is present in schools.

In Kirinyaga east district, Murage (2017) undertook a study that sought to examine challenges facing student councils in discipline management aspects. The study used a target population composed of principals, teachers, members of student councils, and students both in day and boarding schools. Murage (2017) documented that the student councils faced diverse challenges in seeking to effect conflict management. These challenges included being reported to school authorities, parental interference with the student councils, being victimized by fellow students, being treated like social outcasts, and being targets of violence. The study concluded that the student councils challenges in discipline management emanated from poor induction of the student councils, poor support from the school administration, and in adequate consultation of the school governance. In this context, Murage (2017) recommended that the ministry of education should organize capacity building for the school stakeholders in respect to the role of school councils.

In Zambia, Mboyonga (2018) examined the influence student councils in curbing student riots in the country. The study was a metadata analysis that analysed other studies in respect to the study phenomenon. Amongst the challenges that the student councils faced in conflict management included bureaucracy; adult domination; tokenism, teacher opposition, lack of feedback and training, and irregular meetings owing to the busy academic calendar.

\section{Iv.Research Methodology}

The study was based on the descriptive research design. The descriptive research design seeks to give factual information on the subject phenomenon as the phenomenon is on the ground (Saunders, Lewis, \& Thornhill, 2007). Structured questionnaires were utilized for the purpose of data collection due to ease of data collection and analysis. The sample size of the study constituted a sample of 178 boys and 180 girls who were members of student councils.

\section{v.Research Findings}

\section{Student Councils Challenges in Conflict Resolution}

The study sought to determine the challenges facing student councils in the management of conflict resolution. The results are displayed in Table 1.

\section{Table 1: Challenges Facing Student Councils in Conflict Resolution}

\begin{tabular}{ll}
\hline Challenges in Conflict Resolution & Tally \\
\hline Lack of respect and trust from student & 7 \\
Difficult to solve conflict among student & 7 \\
Lack of skills in conflict resolution & 15 \\
Leaders having their own personal issues & 2 \\
Student Council members makes decisions based on friendship & 10 \\
sometimes making uniformed decision & 5 \\
Student not respect Student councils & 4 \\
Biasness in resolving conflict & 4 \\
Treats from other student & 11 \\
Not respected by other students & 8 \\
Hard to ensure students have all they need & 3 \\
Lack different ways of resolving conflict & 4 \\
Refuse to listen junior student & 2 \\
Poor mediation skills & 17 \\
\hline
\end{tabular}

Information in Table 1 indicates the existence of various circumstantial challenges facing student council members in the management of conflict resolution duties. The respondents felt that poor mediation skills; lack of skills in conflict resolution and show of favouritism as well as threats from other student were the main challenges that faced by student councils in conflict resolution in public boarding secondary schools. Further, it was noted that most Council member's makes decisions based on friendship or based on whether the student is senior or junior in the school. That undermined the participation of student council in resolving conflict emanating from students' thus impacting negatively in management of public boys' and girls' boarding secondary schools. 


\section{Enhancing Participation in Conflict Resolution}

The study sought to find out the suggestions of what can be done to address the challenge faced by student councils in executing their conflict resolution roles. The results are displayed in Table 2.

\section{Table 2: Enhancing Participation in Conflict Resolution}

\begin{tabular}{ll}
\hline Conflict Resolutions Strategies & Tally \\
\hline Organized forums to train students in conflict resolution & 24 \\
Guidance and counselling counselling & 27 \\
Guide SC in sorting out hard issues reported & 3 \\
Sensitize student on conflict resolution & 7 \\
Students should be advised to respect their leaders & 3 \\
Encourage upright behaviour and characters & 10 \\
SC should first win student respect & 5 \\
Advise the student to listen to advice given by SC & 5 \\
Involve student in decision making & 8 \\
Address nepotism and stop favouritism & 8 \\
\hline \multicolumn{2}{c}{ The results contained in Table 2 indicate the respondents' suggestions as to how participation of student } \\
councils enhance conflict resolution. The respondents suggested guidance and counselling; organization of forums \\
to train student councils on conflict resolution strategies and encouragement of upright behaviour and characters \\
in order to resolve conflicts among students. This will go a long way to creating a cohesive learning environment \\
in public boys' and girls' boarding secondary schools.
\end{tabular}

\section{Participation of Student Council in Communication}

An item had been introduced in the questionnaire which sought to establish the participation of student council in communication in enhance management of public boys' and girls' boarding secondary school whose finding are presented as follows. The study therefore sought to establish the influence of participation of student councils in communication to enhance management of public boys' and girls' boarding secondary schools. A Five level Likert scale items measured the participation of student councils in communication. The pertinent results are presented in Table 3.

Table 3: Participation of Students Councils in Communication

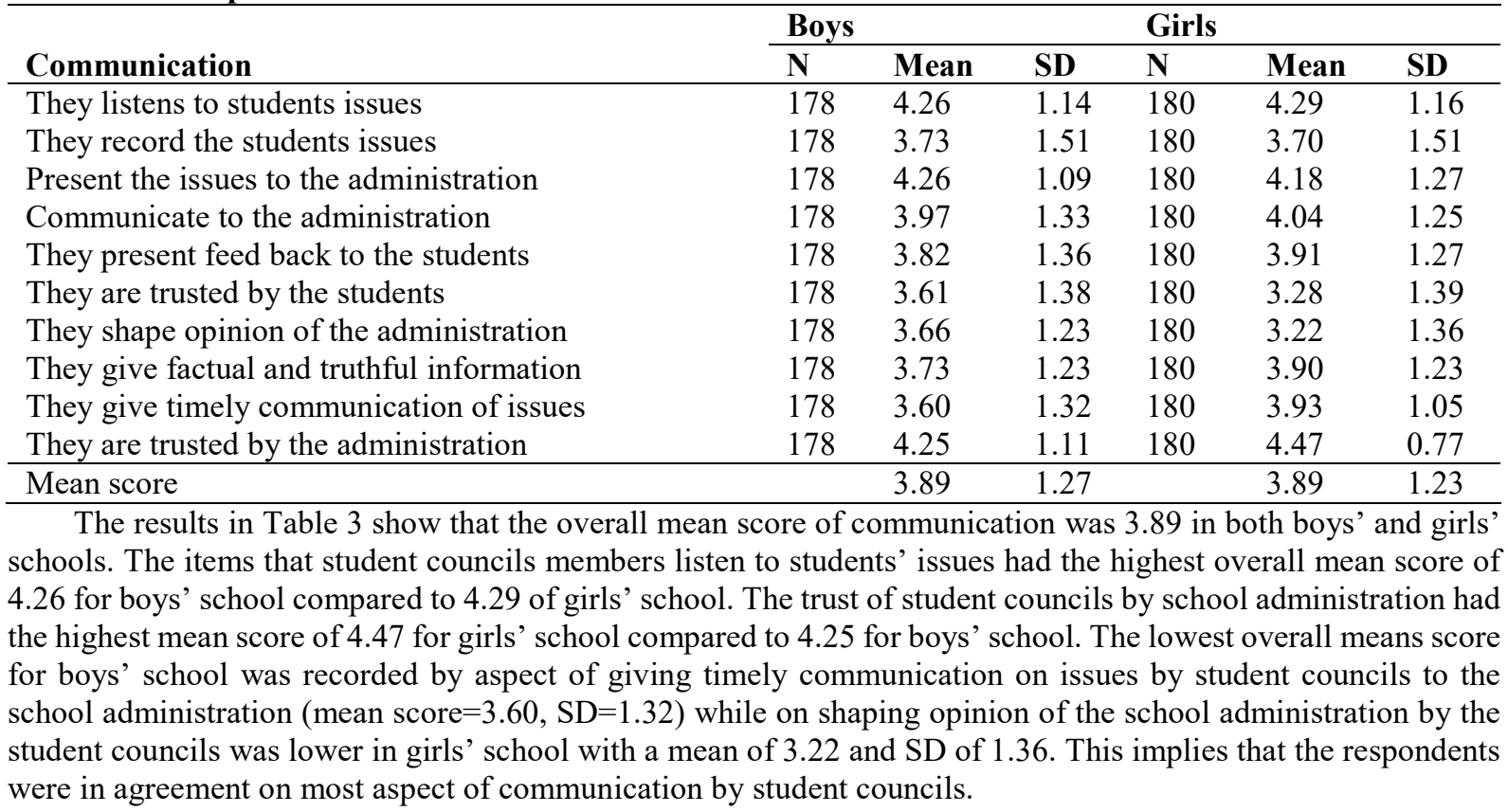

Challenges of Communication in School Management

The study sought to find out the challenges facing student councils participation in communication in public boys' and girls' boarding secondary schools and results are displayed in Table 4. 
Table 4: Challenges of Student Councils in Communication

\begin{tabular}{ll}
\hline Participation in communication & Percent \\
\hline Poor mastery of English and Kiswahili languages & 26 \\
Inability to report promptly due to packed school programs & 7 \\
Lack of confidence & 13 \\
Lack of trust from other student, they are usually branded traitors & 3 \\
Self-esteems issues & 7 \\
They do not communicate sensitive information to the administration & 3 \\
Lack of timely communication from students and the administration & 7 \\
Lack of communication channels & 16 \\
Speaking in vernacular & 13 \\
Use of rude language leading to annoyance to other student & 7
\end{tabular}

The results contained in Table 4 indicate the existence of a number of contextual challenges facing student council in their participation in communication to enhance management of public boys' and girls' boarding secondary schools. The respondents felt that poor mastery of English and Kiswahili languages ; lack of communication channels; speaking in vernacular and lack of confidence were the main communication constraints faced by student councils in the management of public boys' and girls' boarding secondary schools. This suggests that there is communication breakdown between student councils and school management in public boys' and girls' boarding secondary schools.

\section{Enhancing Student Councils Participation in Communication}

The study sought suggestions from the respondents in order to enhance student councils participation in communication to enhance management of public boys' and girl' boarding secondary schools. The pertinent results are displayed in Table 5.

Table 5: Enhancing Student Councils Participation in Communication

\begin{tabular}{lc}
\hline Participation in Communication & \\
\hline Build their confidence by allowing them to address assemblies & 15 \\
Elect SC who communicate in English and Kiswahili fluently & 6 \\
Encourage open communication where there is no fear of intimidation & 11 \\
Enforce use of English and Kiswahili by all students & 9 \\
Use a suggestion boxes for student to report promptly & 32 \\
Ban use of vernacular languages in communication in school & 21 \\
Use of polite but firm language when communication to student & 6 \\
\hline
\end{tabular}

Information contained in Table 5 gives suggested strategies to enhance student councils communication in school management. In order to address communication challenges the following strategies were suggested: use of suggestion boxes to enable student report promptly; Promote the use of English and Kiswahili and stop abusive language; building confidence by allowing student councils to address assemblies, parent meetings and expose them to many activities in and outside the school as well as encouraging open system of communication where there is no fear of intimidation. These would assist in enhancing participation of student councils in communication in management of student affairs in pubic boys' and girls' boarding secondary schools in Nyeri County.

\section{vi. Conclusions}

The study concluded that the student councils faced diverse challenges in conflict management and in communication aspects related to conflict management. There was therefore need for the school administration to support the student councils in order to prevent conflicts and speedily resolve the same when they arise.

\section{References}

Betty, T. J., Kiprop, C., \& Bomett, E. (2017). The Nature of Student Participation in Decision Making in Secondary Schools in Kenya. International Journal of Current Research, 3(10), 186-193.

Edet, A. O., Benson, U. R., \& Williams, R. E. (2017). Principals' Conflict Resolution Strategies and Teachers ' Job Effectiveness in Public Secondary Schools in Akwa Ibom State, Nigeria. Journal of Education and Social Research, 7(2), 153-158.

Hagan, C. (2016). Assessing The Effectiveness Of Conflict Resolution Measures In Public Senior High Schools In The Atwima Nwabiagya District. Unpublished Master of Philosophy (Education Leqadership) Thesis: University of Education, Winneba.

Kipyego, L. B. (2013). Conflict Management Methods Used By Secondary Schools Head Teachers : A Case Of Nandi Central District, Nandi County, Kenya. Unpublished Master of Education (Administration) Thesis: 
Kenyatta University.

Kyalo, K. D., Kanori, E., \& Njagi, L. W. (2017). Influence of Student Councils ' Involvement as a Link of Communication between Students and Administration on Students Discipline in Public Secondary Schools in Kathonzweni Sub County, Kenya. Stratford Peer Reviewed Journals and Books, 1(1), 46-55.

Mboyonga, E. (2018). The Role of Student Representative Councils in Curbing Students ' Riots in Selected Secondary Schools of Chipata District ,. International Journal of Humanities Social Sciences and Education (IJHSSE), 5(3), 36-43.

Mburu, D. M. (2012). Factors Influencing The Implementation Of Safety Standards In Secondary Schools In Limuru District, Kiambu County, Kenya. Unpublished Master of Project Planning and Management Thesis: University of Nairobi.

Murage, L. M. (2017). Challenges facing Student Councils on Management of Discipline in Secondary Schools and Measures Put in place in Kirinyaga East District, Kenya. IOSR Journal of Humanities and Social Science (IOSR-JHSS), 22(7), 40-51.

Murage, L. M., Mwaruvie, P. J., \& Njoka, J. (2017). Influence of Student Councils on Management of Discipline in Secondary Schools in Kirinyaga East District, Kenya. IOSR Journal of Humanities and Social Sciences, 22(7), 52-63. https://doi.org/10.9790/0837-22070165263

Muthui, E. M., \& Barchok, H. K. (2017). Participation Of Student Councils In Communication To Enhance Effective Management Of Secondary Schools In Nyeri County, Kenya. International Journal of Innovative Research and Adanced Studies (IJIRAS), 4(6), 136-144.

Ngema, J. (2013). Fire Disaster Preparedness Strategies in Secondary Schools in Nyeri Central District, Kenya. Unpublished Master of Education in Emergencies: University of Nairobi.

Nyasio, O. J. A. (2015). Factors Influencing Conflict Among The Teaching Staff In Public Secondary Schools In Starehe Division, Nairobi County, Kenya. Unpublished Master of Arts in Project Planning and Management Thesis: University of Nairobi.

Oboegbulem, A., \& Alfa, I. A. (2013). Conflict Resolution Strategies in Non-government Secondary Schools in Benue State, Nigeria. US-China Education Review, 3(2), 91-102.

Ogol, J., \& Thinguri, R. (2017). A Critical Analysis of Effectiveness of Student Council Leadership on Learners Discipline Management in secondary schools in Kenya. International Journal of Applied Research, 3(1), 9097.

Ogonyo, Z. (2012). Implementation of Safety Standards and Guidelines in Public Secondary Schools in Marani District, Kisii County, Kenya. Unpublished Master of Education Thesis: Kenyatta University.

Orapeleng, R. (2017). Innovative Leadership In Managing Conflict At Selected Senior Secondary Schools In Botswana. Unpublished Doctor of Education Thesis: University of South Africa.

Owande, J. O. (2015). Influence Of Prefects 'Involvement In Management On Conflict Resolution In Public Secondary Schools : The Case Of Kisumu County. Unpublished Master of Arts In Peace Education Thesis: University of Nairobi.

Saunders, M., Lewis, P., \& Thornhill, A. (2007). Research Methods for Business Students (4th ed.). England, Harlow, Essex CM20 2JE, England: Pearson Education Limited.

Simatwa, L. K., Ngala, F., \& Tikoko, B. (2017). Advances in Education and Philosophy Influence of Student Councils' Communication Roles on Curbing Frequency of Student Unrests in Public Boys Boarding Secondary Schools in Elgon Sub-. Journal of Advances in Education and Philosophy, 2(5), 484-491.

Vundi, S. (2017). Efficacy of Socialization Tactics Employed to Prepare Student Council Leaders for Conflict Management by in Their Schools Within Kakamega County, Kenya. International Journal of Scientific and Education Research, 1(01), 83-96.

Vundi, S., Majanga, E., \& Odollo, L. (2014). Effects of Socializing Student Council Leaders On Conflict Management In Secondary Schools Within Kakamega County, Kenya. International Journal of Education and Research, 2(7), 263-280.

Wairimu, K. M. (2016). The Effectiveness Of Communication In Conflict Resolution Between Administration And Teaching Staff In Public Secondary Schools In Gatanga Sub-County In Murang'a County, Kenya. Unpublished Master of Arts in Communication Studies Thesis: University of Nairobi.

Wangui, N. H. (2015). Factors Influencing Disaster Management Preparedness In Public Secondary Schools In Nakuru Sub County, Nakuru County. Unpublished Master of Arts in Project Planning and Management Thesis: University of Nairobi.

Wanzala, O., \& Muinde, J. (2018). Rioting Kirmara Students Beat up and Injure Deputy Principal. Retrieved from https://www.nation.co.ke/news/List-of-schools-hit-by-unrest/1056-3318282-14epye8/index.html

Zablon, N. O., Areba, N. G., Monga, E., Rael, O., \& Robert, M. (2014). Implementation of Safety Standards and Guidelines In Public Secondary Schools In Marani District, Kisii County, Kenya . Journal of Education and Practice, 5(13), 111-124. 